\section{RADIATION CHEMISTRY}

\section{Estimation of the Levels of Cæsium-137 in Sea-water by the Analysis of Marine Organisms}

IT is necessary to know the levels of cæsium-137 in sea-water which has been released by nuclear explosions or waste disposal, although the sampling of a large volume of sea-water, usually 100 litres or more, is not always easy or convenient.

Since the weight of marine organisms equivalent to the sea-water with respect to potassium or natural cæsium content is only one-thirtieth or less, the analysis of the former in place of the latter might supply convenient means of estimating the oceanic level of cæsium-137 if an equilibrium is assumed between them.

We have analysed various marine organisms collected in the vicinity of Japan for both natural cæsium-133 and radioactive cæsium-137; the former being analysed by a neutron activation method (to be described elsewhere) and the latter by a radiochemical separation followed by low-background $\beta$ counting ${ }^{1}$. The results obtained are shown in Table 1 .

Table 1. Estrmates of Concentration of Cesium-137 in Sea-

\begin{tabular}{|c|c|c|c|c|}
\hline $\begin{array}{l}\text { Time of } \\
\text { sampling }\end{array}$ & Locality & Organisms & $\begin{array}{c}{ }^{137} \mathrm{Cs} / \\
{ }^{133} \mathrm{Cs} \\
\left(\times 10^{8}\right)\end{array}$ & $\begin{array}{c}\text { Estimate of } \\
{ }_{137} \mathrm{Cs} \text { in } \\
\text { sea-water* } \\
\text { ( } \mu \mu \mathrm{c} . / 1 .)\end{array}$ \\
\hline Dec. 1958 & Suruga Bay & $\begin{array}{l}\text { Sergestes lucens } \\
\text { (shrimp) }\end{array}$ & & (M) \\
\hline March 1959 & Sagami Bay & Diatoms & $\mathbf{3} \cdot 7$ & 1.9 \\
\hline June 1959 & Tokyo Bay & $\begin{array}{l}\text { Neomysis japonica } \\
\text { (zooplankton) }\end{array}$ & $1 \cdot 2$ & $0 \cdot 6$ \\
\hline Aug. 1959 & Sagami Bay & $\begin{array}{l}\text { Eisenia bicyclis } \\
\text { (brown seaweed) }\end{array}$ & $1 \cdot 6$ & 0.8 \\
\hline Aug. 1959 & Tokyo Bay & $\begin{array}{l}\text { Tapes japonica } \\
\text { (littleneck clam) }\end{array}$ & $2 \cdot 0$ & $1 \cdot 0$ \\
\hline March 1960 & W. Pacific & $\begin{array}{l}\text { Sardinops melanostica } \\
\text { (Japanese sardine) }\end{array}$ & 0.8 & $0 \cdot 4$ \\
\hline March 1960 & Japan Sea & $\begin{array}{l}\text { Euphausia pacifica } \\
\text { (zooplankton) }\end{array}$ & $1 \cdot 4$ & $0 \cdot 7$ \\
\hline Oct. 1960 & W. Paciflc & Cololabis saira & $3 \cdot 3$ & $1 \cdot 7$ \\
\hline 1960 & W. Paciflc & $\begin{array}{l}\text { Sphyraena sp. } \\
\text { (barracuda) }\end{array}$ & $3 \cdot 3$ & $1 \cdot 7$ \\
\hline 1960 & W. Pacifle & $\begin{array}{l}\text { Lateolabrax japonicus } \\
\text { (Japanese sea bass) }\end{array}$ & $1 \cdot 6$ & $0 \cdot 8$ \\
\hline 1960 & W. Pacifle & $\begin{array}{l}\text { Trachurus japonicus } \\
\text { (jack mackerel) }\end{array}$ & $1 \cdot 5$ & $0 \cdot 8$ \\
\hline 1961 & W. Pacific & $\begin{array}{l}\text { Cololabis saira } \\
\text { (Pacific saury) }\end{array}$ & $0 \cdot 8$ & 0.4 \\
\hline 1961 & W. Pacific & $\begin{array}{l}\text { Sphyraena sp. } \\
\text { (barracuda) }\end{array}$ & $1 \cdot 0$ & 0.5 \\
\hline 1961 & W. Pacific & $\begin{array}{c}\text { Lateolabrax japonicus } \\
\text { (Japanese sea bass) }\end{array}$ & $2 \cdot 3$ & $1 \cdot 2$ \\
\hline 1961 & W. Pacific & $\begin{array}{l}\text { Trachurus japonicus } \\
\text { (jack mackerel) }\end{array}$ & 0.7 & $0 \cdot 4$ \\
\hline
\end{tabular}

* On the basis of the concentration of cæsium-133 in sea-water being $0.5 \mu \mathrm{gm}$. $/ 1$.

When an equilibrium has been attained between sea-water and marine organisms, the ratio of cæsium$137 /$ cæsium-133 in the former should be equal to that in the latter. On the basis of the concentration of eæsium-133 in sea-water being $0.5 \mu \mathrm{gm}$./1., as given by Smales and Salmon for the Atlantic ${ }^{2}$, and assuming this value is also valid for the Pacific and coastal waters, we have estimated the levels of cæsium-137 in sea-waters as given in the last column of Table 1.

The estimate indicates somewhat higher values for coastal waters in 1959 than those given by one of us previously for 14 samples of surface waters, namely, $0.38 \mu \mu \mathrm{c} . / \mathrm{kgm}$. on the average ${ }^{3}$. The estimate in the Western Pacific in October 1961 from 4 species of fish, 0.6 urc./l. on the average, is approximately half that in the same month of the preceding year, 1.3 uuc./1. These values are much higher than those in the Atlantic or the Eastern Pacific, as already mentioned by Miyake et $a l .{ }^{4}$.
It is interesting to note that the concentration of cæsium-133 is fairly constant, as shown in Table 2 , in several fish species which are popularly consumed in Japan. Presumably, this will be caused by the homogeneous distribution of cæsium-133 in the ocean and the biological insignificance of the chemical element. The standard deviation of the cesium-133 content in different species around the mean value of $21 \mu \mathrm{gm}$./ $\mathrm{kgm}$. is \pm 12 per cent. Accordingly, the analysis of cæsium-133 will not be necessary in the rough estimation of the levels of cæsium-137 in sea-water so far as those fishes are used as monitor.

Table 2. Casium-133 Content of SOME Fishes Fish Cæsium-133 $\mu \mathrm{gm}$. $/$ fresh $\mathrm{kgm}$.

Cololabis saira (Pacific saury) Sphyraena sp. (barracuda)

Lateolabrax japonicus (Japanese sea bass)

Trachurus japonicus (jack mackerel)

A kind of flatfish*

Avera.ge

* Japanese name, 'karei'. (whole body)

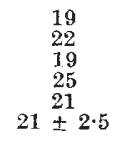

Thus, it may be concluded that the estimation of the levels of cresium-137 in sea-water can conveniently be made by analysing approximately $100 \mathrm{gm}$. fresh weight of the whole body of some kind of fish for cæsium-137, although it should be kept in mind that the estimate does represent the concentration of crsium-137 in sea-water of not a fixed point but an average in space, depth and time, reflecting the lifehistory of an organism.

\section{Rinnosuke Fukat}

Tokai Regional Fisheries Laboratory.

\section{Noboru Yamagata}

Institute of Public Health, Tokyo.

1 Yamagata, N., and Yamagata, T., Analyst, 85, 282 (1960)

${ }^{2}$ Smales, A. A., and Salmon, L., Analyst, 80, 37 (1955).

${ }^{3}$ Yamagata, N., Nature, 184, 1813 (1959).

4 Miyake, Y., et al., J. Rad. Res.,2, 25 (1961).

\section{'Hot'-Atom Chemistry of Radiocobalt in Hexamminecobalt(III) Hexacyano- cobaltate(III) and Hexamminecobalt(III) Hexacyanoferrate(III)}

BeHAVIOUR of cobalt- 60 recoils arising from thermal neutron capture and isomeric transition on cobalt atoms in either hexamminecobalt(III) complex salts or hexacyanocobaltate(III) complex salts has already been investigated ${ }^{1-6}$. However, the system which contains both $\mathrm{NH}_{3}$ and $\mathrm{CN}$ groups together has not yet been investigated. In order to elucidate the role of CN groups in recoil reactions, we selected, as such a system, two complex salts of the formula $\left[\mathrm{Co}\left(\mathrm{NH}_{2}\right)_{6}\right]$ $\left[M(\mathrm{CN})_{6}\right]$, where $M=\mathrm{Co}$ or $\mathrm{Fe}$, since no hexamminecobalt(III) cyanide is known at present.

Solid complex salts $\left[\mathrm{Co}\left(\mathrm{NH}_{3}\right)_{6}\right] \quad\left[\mathrm{Co}(\mathrm{CN})_{6}\right]$ and $\left[\mathrm{Co}\left(\mathrm{NH}_{3}\right)_{6}\right]\left[\mathrm{Fe}(\mathrm{CN})_{6}\right]$, were prepared by the methods described in literature and were subjected to neutron irradiation in an experimental hole in the JRR-1 reactor for 5-6 hr. at pile temperature. Thermal neutron flux was approximately $3 \times 10^{11} \mathrm{n} . / \mathrm{cm}^{2}$. sec. After varied storage time following the irradiation the irradiated salts were dissolved in $0.3 \mathrm{M}$ hydrochloric acid and species labelled with cobalt-60 were separated by procedures involving ion exchange, paper electrophoresis, recrystallization, or a combination of these. Essentially the same distribution of 